\title{
DAERAH PENANGKAPAN IKAN KEMBUNG (Rastrelligger $s p$ ) DI SELAT SUNDA PADA MUSIM PERALIHAN
}

\section{POTENTIAL FISHING ZONES Rastrelligger sp IN SUNDA STRAIT IN TRANSITIONAL SEASON}

\author{
Daniel Julianto Tarigan, Ferry Dwi Cahyadi, Agung Setyo Sasongko, Lio Yonanto, Bella Dinda Rahayu \\ Program Studi Pendidikan Kelautan dan Perikanan, \\ Universitas Pendidikan Indonesia \\ Korespondensi: danieljulianto@upi.edu
}

\begin{abstract}
Mackerel is the dominant species caught in the waters of the Sunda Strait. The fishing grounds has a very strong influence on oceanographic conditions such as temperature and chlorophyll-a. Sea surface temperature is an indicator for measuring phenomena that occur in the oceans such as currents, upwelling, fronts, while chlorophyll-a is an indicator of the fertility of a waters. The aspect of fish length is the main focus in determining fishing grounds. This study aims to analyze the catch based on chlorophyll-a, sea surface temperature, and fish length which results in mapping the fishing grounds for mackerel in the Sunda Strait waters. This research was conducted by using the case method. The analysis used in this study is the scoring associated with chlorophyll-a, sea surface temperature, fish length, and CPUE. The length of the fish is the aspect that has the greatest weight. The fishing grounds category consists of potential, medium potential and non-potential fishing categories. Based on the research results, the total catch of mackerel in the waters of the Sunda Strait during the study was $741 \mathrm{~kg}$. The catch size category of fish is in the fishing grounds of Peucang Island, Panaitan Island, Paraja Bay, and Tanjung Alang-Alang. The overall chlorophyll-a content is in the high category. The fishing grounds that are included in the potential category are Peucang Island, Panaitan Island, Tanjung Alang-Alang, and Paraja Bay, while the fishing grounds that do not have the potential are Tanjung Lesung, Sumur, Sebesi, Tanjung Ketapang, dan Rakata.
\end{abstract}

Keywords: chlorophyll-a, fishing grounds, mackerel, Sunda Strait

\section{ABSTRAK}

Ikan kembung merupakan spesies yang dominan tertangkap di Perairan Selat Sunda. Daerah penangkapan ikan memiliki karakteristik yang sangat dipengaruhi kondisi oseanografi seperti suhu dan klorofil-a. Suhu permukaan laut merupakan indikator untuk mengukur fenomena-fenomena yang terjadi di lautan seperti fenomena arus, upwelling, front sedangkan klorofil-a yang merupakan indikator kesuburan suatu perairan. Aspek ukuran panjang ikan menjadi fokus utama dalam menentukan daerah penangkapan ikan. Penelitian ini bertujuan untuk menganalisis hasil tangkapan berdasarkan klorofil-a, suhu permukaan laut, dan ukuran panjang ikan yang menghasilkan pemetaan daerah penangkapan ikan kembung di Perairan Selat Sunda. Penelitian ini dilakukan dengan metode kasus. Analisis yang digunakan dalam penelitian ini yaitu skoring terkait dengan klorofil-a, suhu permukaan laut, ukuran panjang ikan, dan CPUE. Ukuran panjang ikan merupakan aspek yang memiliki bobot terbesar. Kategori daerah penangkapan ikan terdiri dari kategori daerah penangkapan ikan potensial, potensial sedang, dan tidak potensial. Berdasarkan hasil penelitian, jumlah hasil tangkapan ikan kembung di Perairan Selat Sunda selama penelitian yaitu $741 \mathrm{~kg}$. Kategori ukuran ikan layak tangkap terdapat di daerah penangkapan Pulau Peucang, Pulau Panaitan, Teluk Paraja, dan Tanjung Alang-Alang. Kandungan klorofil-a secara keseluruhan termasuk kategori tinggi. Daerah penangkapan yang termasuk kategori potensial yaitu Pulau Peucang, Pulau Panaitan, Tanjung Alang-Alang, dan Teluk Paraja sedangkan daerah penangkapan yang tidak potensial yaitu Tanjung Lesung, Sumur, Sebesi, Tanjung Ketapang, dan Rakata.

Kata kunci : daerah penangkapan ikan, ikan kembung, klorofil-a, Selat Sunda 


\section{PENDAHULUAN}

Pada umumnya nelayan yang pergi untuk melaut tidak mengetahui kemana mereka akan pergi untuk mencari ikan. Nelayan hanya mengandalkan insting dan pengalaman yang ada dalam mencari daerah penangkapan ikan yang dituju. Namun kenyataannya, daerah yang dituju tidak selalu menghasilkan jumlah ikan yang cukup melimpah, sehingga nelayan harus mencari daerah penangkapan ikan yang menyebabkan biaya operasional yang cukup tinggi, waktu operasional yang lama, dan tenaga yang lebih (Simbolon 2017). Hal ini menyebabkan operasi penangkapan ikan menjadi tidak efisien, sehingga perlu dilakukan suatu penelitian untuk mengetahui daerah penangkapan ikan yang potensial. Penelitian daerah penangkapan ikan potensial ini dapat dilakukan melalui pendekatan analisis kandungan fitoplankton (klorofil-a), CPUE, dan ukuran panjang ikan.

Keberadaan fitoplankton tersebar luas di perairan, namun penyebarannya sangat tergantung ketersediaan nutrient dan intensitas cahaya matahari. Bila nutrient dan intensitas cahaya matahari cukup tersedia, maka konsentrasi klorofil akan tinggi dan sebaliknya bila nutrient dan intensitas cahaya matahari tidak cukup tersedia, maka konsentrasi klorofil akan rendah (Tubalawony 2008). Oleh karena itu, setiap perairan memiliki sebaran fitoplankton yang berbeda. Perbedaan tersebut dapat membentuk sebuah pola sebaran yang dapat diamati secara spasial (jarak) dan temporal (waktu).

Pengamatan pola sebaran dapat dilakukan dengan menggunakan data citra satelit dan data posisi hasil tangkapan. Data klorofil-a hasil citra satelit dapat menggambarkan penyebaran fitoplankton. Sedangkan data suhu permukaan laut dapat menggambarkan fenomena upwelling. Salah satu citra yang dapat digunakan untuk mendeteksi penyebaran fitoplankton dan suhu permukaan laut adalah citra satelit dengan sensor MODIS. Pengamatan fitoplankton dan suhu permukaan laut melalui satelit atau sering disebut dengan pengamatan ex-situ (tidak langsung) tidak membutuhkan biaya terlalu besar untuk pengamatan, tidak membutuhkan waktu yang lama dan hemat tenaga dibandingkan dengan pengamatan in-situ (langsung).

Selain klorofil-a, produktivitas penangkapan dan ukuran panjang ikan juga sangat penting dipertimbangkan untuk menentukan kondisi daerah penangkapan. Penangkapan ikan tanpa mempertimbangkan ukuran panjang ikan dengan kata lain, ikan yang tertangkap di dominasi oleh ukuran yang kecil, maka akan menyebabkan terjadinya degradasi pada sumberdaya ikan tersebut. Ukuran panjang ikan dapat menggambarkan terjadinya overfishing di daerah tersebut (Simbolon 2020).

Selat Sunda merupakan bagian dari wilayah pengelolaan perikanan (WPP) 572 yang mempunyai potensi perikanan yang melimpah. Hal ini dikarenakan Selat Sunda merupakan daerah pertemuan antara Samudera Hindia dan Laut Jawa yang merupakan sumber nutrient. Selat Sunda memiliki banyak ikan hasil tangkapan yaitu ikan lemuru, tembang, teri, tongkol, peperek, laying, dan salah satu hasil tangkapan yang cukup banyak yaitu ikan kembung. Menurut Siregar (2015) hasil tangkapan ikan kembung mencapai 556 ton/tahun. Hal ini menunjukkan hasil tangkapan ikan kembung cukup tinggi di Perairan Selat Sunda. Selain itu ikan kembung memiliki nilai ekonomis dan memiliki gizi yang cukup tinggi.

Penelitian tentang ikan kembung di Selat Sunda sudah banyak dilakukan, diantaranya Prahadina et al. (2015), Sarasati et al. (2016), Lubis et al. (2019), Salsabila dan Affandi (2019) terkait klorofil-a kebiasaan makan. Namun penelitian tentang pemetaan daerah penangkapan ikan kembung di Selat Sunda berdasarkan produksi, kandungan klorofil-a, dan ukuran panjang ikan perlu untuk dilakukan. Oleh karena itu, tujuan dari penelitian ini adalah (1) menentukan komposisi jumlah dan produktivitas (CPUE) ikan kembung, (2) menganalisis komposisi ukuran panjang (size) ikan kembung, (3) menganalisis sebaran spasial kandungan klorofil, (4) mengevaluasi dan memetakan daerah penangkapan ikan kembung yang potensial pada musim peralihan II di Perairan Selat Sunda. Hal ini perlu dilakukan agar informasi daerah penangkapan ikan kembung di perairan Selat Sunda lebih komprehensif dan akurat.

\section{METODE PENELITIAN}

\section{Tempat dan waktu penelitian}

Penelitian ini dilakukan di Perairan Selat Sunda dengan mengamati spot-spot penangkapan dimana kapal yang berbasis 
di PPP Labuan (Gambar 1). Titik lokasi penangkapan yang diamati yaitu P. Peucang, Tj. Lesung, Sumur, Sebesi, Tj. Ketapang, P. Panaitan, Rakata, Tj.Alang-Alang, dan Teluk Paraja. Penelitian dilaksanakan selama 2 bulan dengan dua tahap pengambilan data. Tahap pertama adalah pengambilan data di PPP Labuan, Banten pada bulan September hingga Oktober. Tahap kedua adalah mengunduh citra klorofil-a hasil deteksi AquaMODIS dari internet.

\section{Pengumpulan data}

Penelitian daerah penangkapan ikan kembung dilakukan dengan metode studi kasus. Metode ini digunakan karena unit penelitiannya kecil atau terbatas. Penelitian ini menggunakan data primer dan data sekunder dengan purposive sampling. Dasar pertimbangan purposive sampling ini adalah kapal sampel beroperasi di lokasi penelitian, kapal sampel beroperasi di laut bebas, alat tangkap yang dioperasikan sesuai dengan ikan yang menjadi objek penelitian, pemilik kapal memberi izin untuk dilakukan wawancara dan narasumber memiliki kemampuan yang baik untuk menjawab pertanyaan (Simbolon 2017). Data primer diperoleh dengan dua cara yaitu dengan pengamatan langsung dan penyebaran kuesioner. Data pengamatan langsung diperoleh dari armada penangkapan ikan pelagis kecil yang berbasis di PPP Labuan. Berdasarkan hasil identifikasi terhadap jenis dan jumlah populasi armada penangkapan ikan kembung, ditentukan kapal sampel sebagai obyek penelitian secara sengaja (purposive sampling).

Data yang diambil dari kapal sampel tersebut meliputi waktu dan posisi operasi penangkapan ikan, kondisi daerah penangkapan ikan, komposisi jumlah, jenis tangkapan pada setiap posisi, waktu operasi penangkapan ikan, dan ukuran panjang ikan yang dominan tertangkap. Pengumpulan data ukuran ikan dilakukan dengan tahapan sebagai berikut;

1. Menyortir hasil tangkapan pada setiap daerah penangkapan ikan berdasarkan jenis atau spesies ikan yang tertangkap

2. Menentukan jenis atau spesies ikan yang dominan tertangkap pada setiap daerah penangkapan ikan

3. Mengambil sampel ikan yang dominan tertangkap secara acak untuk diukur panjangnya

4. Mencatat panjang ikan pada logbook yang telah disediakan
Kapal penangkapan ikan di PPP Labuan tidak seluruhnya memiliki GPS (Global Positioning System). Oleh karena itu, data posisi penangkapan ikan diperoleh dengan cara meminta nahkoda untuk memberikan titik daerah penangkapan pada peta yang telah disediakan. Peta yang disediakan merupakan peta yang bersumber dari Bakosurtanal. Kegiatan selanjutnya yang dilakukan adalah pengambilan data sekunder. Data sekunder terdiri dari data produksi, data klorofil-a, dan suhu permukaan laut. Data klorofil-a dan suhu permukaan laut hasil deteksi MODIS diperoleh dengan cara mengunduh dari alamat http://www.oceancolor.gsfc.nasa. gov. Data produksi yang diambil bersifat bulanan dan diperoleh dari laporan statistik PPP Labuan. Selanjutnya data pendukung lainnya seperti data kondisi Perairan Selat Sunda diperoleh melalui penelusuran pustaka.

\section{Analisis data}

\section{Komposisi hasil tangkapan}

Data jumlah dan ukuran hasil tangkapan yang telah diperoleh dianalisis secara deskriptif melalui penyajian tabel atau grafik. Ukuran panjang ikan dikelompokkan menjadi ikan layak tangkap dan ikan yang tidak layak tangkap. Ikan yang layak tangkap merupakan ikan-ikan yang ukurannya lebih besar dari ukuran ikan yang pertama kali matang gonad atau length at first maturity (LM). Penentuan LM ikan kembung dengan mengukur ukuran panjang total ikan kembung, mulai dari mulut hingga bagian akhir ekor. Ikan-ikan yang belum layak tangkap merupakan ikanikan yang ukurannya lebih kecil dari length at first maturity (LM). Persentase dari ikan yang layak tangkap dan ikan yang tidak layak tangkap disajikan dalam bentuk diagram dan dianalisis secara deskriptif.

Hubungan klorofil-a dan suhu dengan hasil tangkapan

Data klorofil-a hasil deteksi Aqua MODIS yang diunduh dari situs http:// www.oceancolor.gsfc.nasa.gov dianalisis menggunakan software SeaDAS (SeaWIFS Data Analysis Sistem) versi 6.4. Langkah yang dilakukan adalah mengunduh data dari citra Aqua MODIS level 3 browser komposisi harian Bulan September 2020 resolusi spasial $4 \mathrm{~km}$. Data MODIS level 
3 merupakan produk data yang sudah diproses. Data tersebut sudah memiliki informasi seperti lintang dan bujur, daratan, garis pantai, dan nilai estimasi konsentrasi klorofil fitoplankton perairan (Meliani 2006). Kemudian dilakukan croping hasil klorofil yang telah diunduh menggunakan SeaDAS sehingga diperoleh hasil dalam format ASCII. Setelah diperoleh data dalam format ASCII pengolahan data dilanjutkan dengan menggunakan Microsoft Excel 2010. Data tersebut kemudian disajikan dalam bentuk grafik. Kemudian untuk mengetahui data klorofil-a sejenis dapat menggunakan uji variabilitas. Varian atau keragaman data merupakan salah satu teknik yang digunakan untuk menjelaskan homogenitas kelompok data. Variabilitas atau keragaman data (sampel) dapat dihitung menggunakan rumus sebagai berikut (Sugiyono 2011):

$$
\begin{gathered}
s^{2}=\frac{\sum_{i=1}^{n}\left(x_{i}-\bar{x}\right)^{2}}{n-1} \\
s=\sqrt{s^{2}} \\
K v=\frac{s}{x} \cdot 100 \%
\end{gathered}
$$

Keterangan :

$s^{2}:$ Ragam contoh

$s$ : Simpangan baku

$x_{i}:$ Konsentrasi klorofil-a $x$ : Rata-rata klorofil-a

$K v:$ Koefisien variasi

Kriteria untuk menentukan

homogenitas adalah semakin kecil nilai $K v$ maka kelompok data semakin homogen, $K v=0$ menandakan setiap elemen data tepat sama (Siregar 2004).

Pengaruh kandungan klorofil-a terhadap hasil tangkapan kembung diduga berpengaruh secara langsung, karena ikan kembung secara langsung mengkonsumsi fitoplankton. Fitoplankton yang direpresentasikan oleh klorofil-a akan mempengaruhi kelimpahan ikan kembung setelah membutuhkan selang waktu beberapa lama (time lag). Oleh karena itu, korelasi antara klorofil-a dengan tangkapan ikan kembung dianalisis dengan uji korelasi Spearman. Menurut Sugiyono (2007) rumus yang digunakan dalam uji korelasi silang adalah:

$$
p=1-\frac{6 x \sum b i^{2}}{n\left(n^{2}-1\right)}
$$

Keterangan:

$p \quad$ : Koefisien korelasi Spearman

$\sum b i^{2}$ : Hubungan konsentrasi klorofil-a dan komposisi hasil tangkapan

n : Jumlah responden

Kriteria yang digunakan untuk menentukan erat tidaknya korelasi antara dua variabel disajikan pada Tabel 1 .

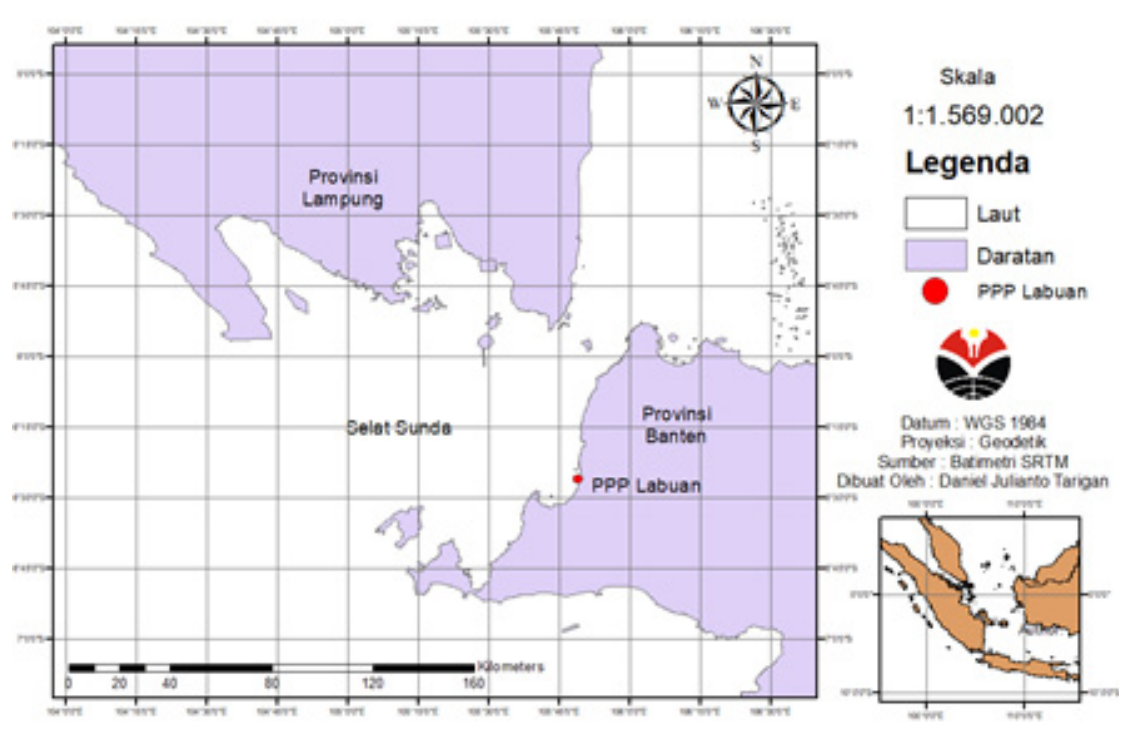

Gambar 1. Peta Lokasi Penelitian 
Tabel 1. Kriteria keeratan antar variabel dependen dengan variabel independen berdasarkan nilai koefisien korelasi silang

\begin{tabular}{cc}
\hline Nilai koefisien korelasi & Korelasi \\
\hline $0,00-0,199$ & Sangat rendah \\
$0,20-0,399$ & Rendah \\
$0,40-0,599$ & Sedang \\
$0,60-0,799$ & Kuat \\
$0,80-1,000$ & Sangat kuat \\
\hline
\end{tabular}

Sumber: Sugiyono (2007)

Pendugaan daerah penangkapan ikan kembung

Penelitian mengenai daerah penangkapan ikan telah dilakukan oleh Surbakti (2012). Indikator yang digunakan adalah konsentrasi klorofil-a dan Catch per Unit Effort (CPUE). Penelitian sejenis juga pernah dilakukan Zen et al. (2005). Indikator yang digunakan untuk menduga daerah penangkapan ikan ada empat, yaitu hasil tangkapan, panjang ikan, salinitas, dan suhu permukaan laut.

Dalam penelitian ini digunakan tiga kriteria untuk menentukan daerah penangkapan ikan yaitu, Catch Per Unit Effort (CPUE), ukuran panjang ikan, dan kandungan klorofil-a. Namun kriteria ukuran panjang ikan lebih besar bobotnya dibandingkan dengan dua indikator lainnya. Hal ini didasari oleh pemikiran bahwa komposisi ukuran ikan yang tertangkap sangat penting peranannya dalam menjaga kelestarian sumberdaya ikan. Hasil tangkapan yang didominasi kategori yang tidak layak tangkap berpeluang besar menimbulkan penurunan laju rekruitmen sehingga kelimpahan stok ikan akan berkurang dalam jangka panjang (Simbolon 2008).

\section{Catch Per Unit Effort (CPUE)}

Catch per unit effort ini menggambarkan produktivitas tangkapan, yaitu jumlah tangkapan per satuan unit waktu. CPUE ini dapat dihitung dengan rumus berikut (Purwaningtyas et al. 2006):

$$
C P U E=\frac{\text { Jumlah hasil tangkapan }(\mathrm{kg})}{\text { Upaya tangkapan }(\text { trip })}
$$

Kategori daerah penangkapan ikan berdasarkan nilai CPUE dianalisis dengan teknik scooring dengan pemberian bobot (Tabel 2). Apabila nilai CPUE lebih besar dari nilai CPUE rata-rata maka diberi bobot 1 dan perairan tersebut dikategorikan sebagai daerah penangkapan ikan potensial. Jika nilai CPUE lebih kecil dari atau sama dengan nilai CPUE rata-rata, maka diberi bobot 0 dan perairan tersebut dikategorikan sebagai daerah penangkapan ikan tidak potensial (Simbolon dan Girsang 2009).

\section{Ukuran panjang ikan}

Data ukuran panjang ikan yang diperoleh dibandingkan dengan panjang ikan pada saat ikan tersebut pertama kali matang gonad atau length at first maturity (LM). Menurut Kasmi et al. (2017), nilai LM ikan kembung pada ukuran 21,13 $\mathrm{cm}$ di Perairan Pesisir Takalar, Sulawesi Selatan. Lokasi penelitian yang dilakukan terletak di Selat Makassar. Menurut peneliti nilai LM ikan kembung Selat Sunda dan Perairan Pesisir Takalar tidak akan berbeda diduga karena dalam satu wilayah perairan Indonesia. Panjang ikan yang tertangkap lebih besar dari LM, maka diberi bobot 3 dan perairan tersebut dikategorikan sebagai daerah penangkapan ikan potensial. Apabila panjang ikan yang tertangkap lebih kecil dari atau sama dengan LM, maka diberi bobot 0 dan periran tersebut dikategorikan sebagai daerah penangkapan ikan tidak potensial (Tabel 3) (Simbolon 2020).

\section{Klorofil-a}

Penentuan kategori daerah penangkapan ikan berdasarkan pendekatan kandungan klorofil-a dianalisis dengan teknik scooring (Tabel 4). Wudianto (2001) menyebutkan bahwa suatu perairan dapat dikategorikan subur apabila kandungan klorofil-a $>0,2 \mathrm{mg} / \mathrm{m}^{3}$. Berdasarkan tingkat kesuburan tersebut, maka karakteristik daerah penangkapan ikan potensial terpenuhi apabila kandungan klorofil-a $>0,2 \mathrm{mg} / \mathrm{m}^{3}$ diberi bobot 1 dan daerah penangkapan ikan tidak potensial terpenuhi apabila kandungan klorofil-a $<0,2 \mathrm{mg} / \mathrm{m}^{3}$ diberi bobot 0 (Simbolon dan Girsang 2009). 
Kategori DPI potensial dan tidak potensial selanjutnya dianalisis berdasarkan indikator CPUE, ukuran ikan, dan klorofil-a yang telah diberi bobot atau skor, kemudian diakumulasikan dan dianalisis secara deskriptif. Kriteria ukuran ikan harus lebih diutamakan dalam rangka mewujudkan penangkapan yang berwawasan lingkungan (Tabel 5). Daerah penangkapan dikatakan potensial apabila memenuhi skor 5 dan 4 . Daerah penangkapan dikatakan potensial sedang jika memenuhi skor 3. Daerah penangkapan dikatakan tidak potensial jika memenuhi skor 1 dan 2 (Tarigan 2016).

Tabel 2. Penilaian DPI melalui indikator CPUE

\begin{tabular}{llccc}
\hline No & Kategori CPUE & Kriteria & Bobot & Kategori DPI \\
\hline 1 & Tinggi & CPUE $>$ CPUE rata-rata & 1 & Potensial \\
2 & Rendah & CPUE $\leq$ CPUE rata-rata & 0 & Tidak Potensial \\
\hline
\end{tabular}

Sumber: Simbolon dan Girsang (2009)

Tabel 3. Penilaian DPI melalui indikator ukuran panjang ikan

\begin{tabular}{llccc}
\hline No & $\begin{array}{c}\text { Kategori Ukuran } \\
\text { panjang }\end{array}$ & Kriteria & Bobot & Kategori DPI \\
\hline 1 & Besar & Panjang ikan > LM & 3 & Potensial \\
2 & Kecil & Panjang ikan $\leq$ LM & 0 & Tidak potensial \\
\hline
\end{tabular}

Tabel 4. Penilaian DPI melalui indikator klorofil-a

\begin{tabular}{llccc}
\hline No & $\begin{array}{c}\text { Kategori kandungan } \\
\text { klorofil-a }\end{array}$ & Kriteria & Bobot & Kategori DPI \\
\hline 1 & Banyak & Klorofil-a $>0,2 \mathrm{mg} / \mathrm{m}^{3}$ & 1 & Potensial \\
2 & Sedikit & Klorofil-a $\leq 0,2 \mathrm{mg} / \mathrm{m}^{3}$ & 0 & Tidak potensial \\
\hline
\end{tabular}

Sumber: Simbolon dan Girsang (2009)

Tabel 5. Penentuan kategori DPI berdasarkan kombinasi nilai bobot dari indikator CPUE, klorofil-a, dan ukuran ikan

\begin{tabular}{clcc}
\hline No & \multicolumn{1}{c}{ Kombinasi Indikator DPI } & Kategori DPI & Skor \\
\hline 1 & $\begin{array}{l}\text { Ukuran ikan besar, CPUE tinggi, } \\
\text { Klorofil-a banyak }\end{array}$ & Potensial & 5 \\
2 & $\begin{array}{l}\text { Ukuran ikan besar, CPUE tinggi, } \\
\text { tetapi Klorofil-a rendah }\end{array}$ & Potensial & 4 \\
3 & $\begin{array}{l}\text { Ukuran ikan besar, Klorofil-a banyak, } \\
\text { suhu optimal }\end{array}$ & Potensial & 4 \\
4 & $\begin{array}{l}\text { CPUE tinggi, Klorofil-a banyak, tetapi } \\
\text { ukuran ikan kecil }\end{array}$ & Tidak Potensial \\
5 & $\begin{array}{l}\text { Ukuran ikan besar, tetapi klorofil-a } \\
\text { rendah, CPUE rendah } \\
\text { CPUE tinggi, tetapi ukuran ikan } \\
\text { kecil, klorofil-a sedikit } \\
7\end{array}$ & $\begin{array}{l}\text { Klorofil-a banyak, tetapi ukuran ikan } \\
\text { kecil, CPUE rendah }\end{array}$ & Potensial Sedang \\
\hline
\end{tabular}




\section{HASIL DAN PEMBAHASAN}

\section{Jumlah produksi ikan kembung}

Jumlah total hasil tangkapan ikan kembung yang didaratkan di TPI 2 Labuan selama penelitian adalah $741 \mathrm{~kg}$ (Gambar 2). Rata-rata hasil tangkapan ikan kembung di Perairan Selat Sunda pada bulan September yaitu $25 \mathrm{~kg}$. Jumlah ikan kembung yang banyak tertangkap pada tanggal 16 September 2020, sedangkan ikan kembung sedikit tertangkap pada tanggal 5 dan 6 September 2020. Hal ini menunjukkan bahwa penangkapan ikan kembung di Perairan Selat Sunda masih banyak dilakukan oleh nelayan Labuan.

Perairan Selat Sunda memiliki hasil tangkapan yang beragam jenis. Jenis ikan dominan yang tertangkap di Selat Sunda yaitu ikan bentong, ikan teri, ikan tenggiri, cumi-cumi, ikan peperek, ikan kuwe, dan ikan kembung. Ikan kembung merupakan salah satu ikan yang dominan tertangkap di Selat Sunda. Hal ini dikarenakan jumlah produksi ikan kembung sebanyak 233 ton/tahun dengan presentase $11 \%$. Ikan kembung merupakan kelompok ikan pelagis kecil yang diminati oleh masyarakat Banten. Permasalahan yang sering dihadapi penangkapan sumberdaya ikan pelagis kecil adalah permasalahan biologi dan ekonomi (Priatna dan Natsir 2008). Permasalahan terkait biologi disebabkan tingginya intensitas penangkapan yang dilakukan sehingga menyebabkan terancamnya sumberdaya ikan dikemudian hari. Alat tangkap yang banyak digunakan untuk menangkap ikan kembung di Selat Sunda yaitu jaring gillnet, purse seine, dan payang. Alat tangkap yang paling efektif digunakan oleh nelayan untuk menangkap ikan kembung adalah alat tangkap purse seine atau pukat cincin (Abubakar et al. 2019). Jumlah total volume produksi ikan dominan yang tertangkap tahun 2019 di PPP Labuan yaitu sebanyak 2086 ton (Gambar 3).

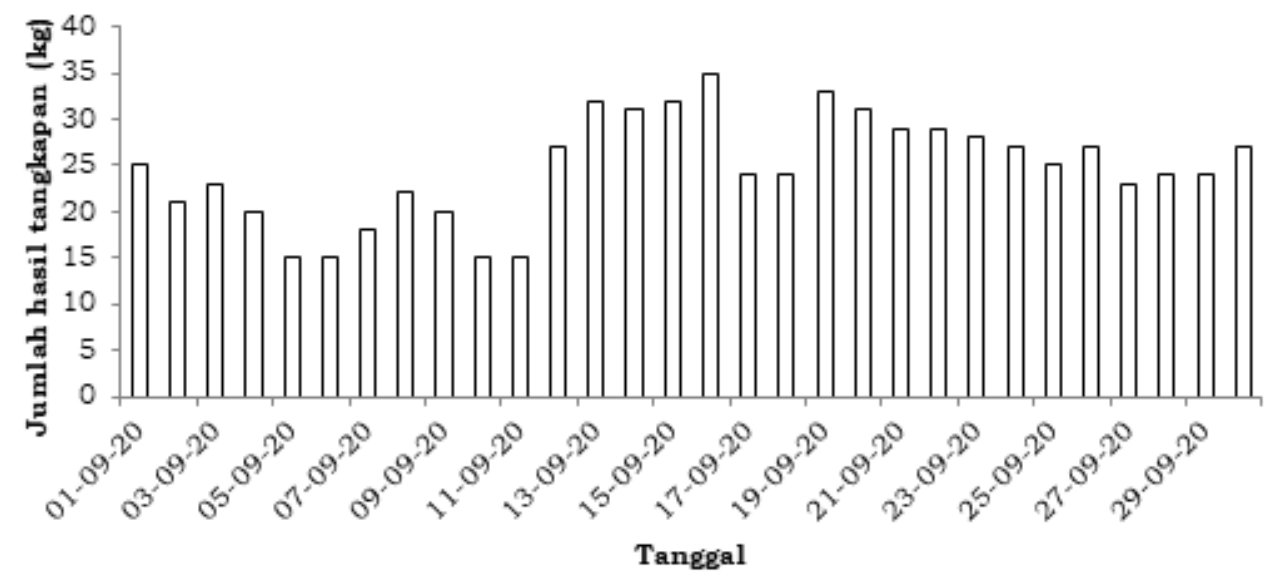

Gambar 2. Jumlah hasil tangkapan ikan kembung selama penelitian

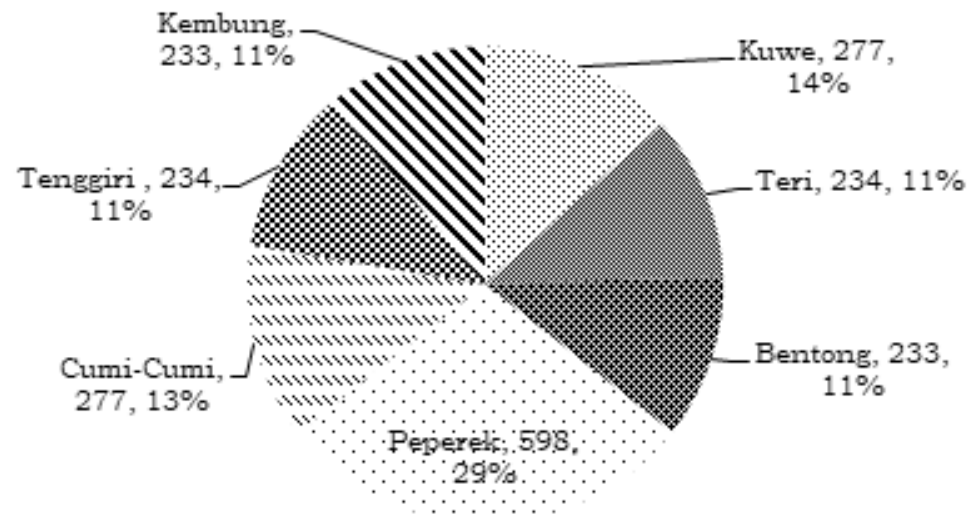

Gambar 3. Jenis ikan dominan yang tertangkap di Selat Sunda (Sumber: PPP Labuan) 
Gambar 4 menunjukkan bahwa jumlah hasil tangkapan ikan kembung selama penelitian sebaran spasial yang beragam. Hasil tangkapan tertinggi terdapat di daerah sekitar Pulau Peucang dengan total $90 \mathrm{~kg}$, sedangkan hasil tangkapan terendah terdapat di daerah sumur $60 \mathrm{~kg}$. Secara keseluruhan jumlah total hasil tangkapan selama penelitian yang menunjukkan masih sedikit. Hal ini diduga jumlah armada yang melaut masih terbatas dikarenakan cuaca yang kurang baik.

\section{Ukuran panjang ikan kembung}

Ikan kembung yang tertangkap di PPP Labuan selama penelitian memiliki sebaran ukuran yang beragam (Tabel 6). Ukuran panjang ikan kembung yang tertangkap terdiri dari 13-24 cm. Ikan kembung paling banyak tertangkap berukuran $19-20 \mathrm{~cm}$ sebanyak 127 ekor (37\%) dan 21-22 cm sebanyak 130 ekor (38\%). Ukuran panjang ikan yang paling sedikit tertangkap selama penelitian berukuran $23-24 \mathrm{~cm}$ yaitu sebanyak 4 ekor (1\%), ikan dengan ukuran 13-14 cm yaitu 24 ekor (6\%), dan ukuran ikan $17-18 \mathrm{~cm}$ yaitu 23 ekor (7\%). Ratarata ukuran ikan yang tertangkap selama penelitian berukuran $19,84 \mathrm{~cm}$ dari total 340 ikan yang tertangkap.

Kasmi et al. (2017) menyatakan bahwa ukuran layak tangkap ikan kembung yaitu 21,13 cm. Ikan kembung yang berukuran lebih dari LM maka dinyatakan layak tangkap, namun ukuran dibawah dari LM dinyatakan ukuran tidak layak tangkap. Oleh karena itu, ukuran ikan layak tangkap selama penelitian sebanyak $40 \%$ dan ukuran tidak layak tangkap sebanyak $60 \%$ (Gambar 5). Hal ini menunjukkan selama musim peralihan barat pada tahun 2020, ikan kembung didominasi ukuran tidak layak tangkap. Komposisi hasil tangkapan agak berbeda dengan penelitian yang dilakukan oleh Ispahdianto et al. (2016) yang menyatakan ikan kembung di Perairan Morodemak yang layak tangkap memiliki presentase $47 \%$ dan tidak layak tangkap $53 \%$, sedangkan Musbir et al. (2006) menyebutkan ikan kembung yang layak tangkap di Perairan Flores sebanyak 50\%. Perbedaan ukuran ikan kembung layak tangkap disebabkan lokasi penelitian, waktu penelitian, alat tangkap yang digunakan dan musim penangkapan ikan kembung yang berbeda. Selain itu perbedaan ukuran panjang ikan kembung dalam populasi disebabkan adanya perbedaan pola pertumbuhan, perbedaan umur pertama kali matang gonad, dan bertambahnya jenis ikan baru pada suatu populasi ikan yang sudah ada (Abubakar et al. 2019).

Ukuran ikan kembung di Perairan Selat Sunda selama penelitian di dominasi ikan yang belum layak tangkap. Oleh karena itu diperlukan pengaturan terhadap ukuran ikan yang tidak layak tangkap yang seharusnya tidak untuk ditangkap. Hal ini sesuai dengan pernyataan Boer dan Aziz (2007) yang menyatakan ikan kembung yang tertangkap masih muda dan seharusnya tidak boleh ditangkap dikarenakan ukuran kecil jika ditangkap terus menerus maka proses rekrutmen tidak akan terjadi lagi sehingga tidak ada ikan yang memijah. Apabila ikan tidak layak tangkap mendominasi hasil tangkapan, berarti bahwa usaha penangkapan mengurangi peluang recruitment dan akan berdampak negatif terhadap ketersediaan stok di perairan (Simbolon 2008).

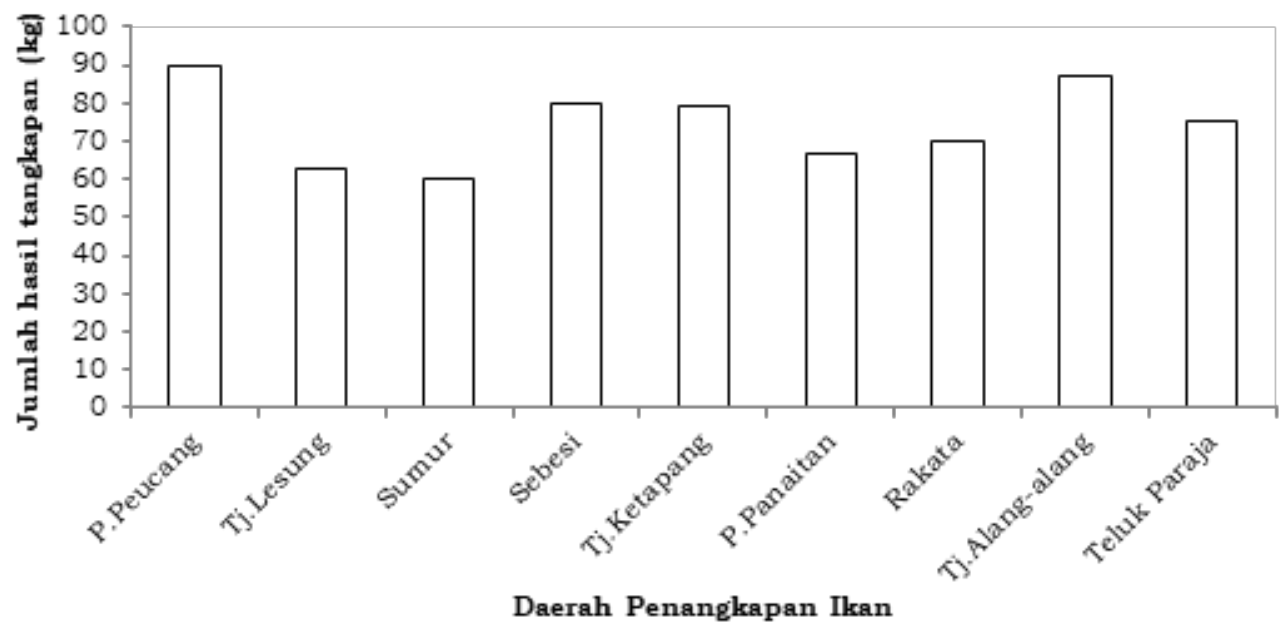

Gambar 4. Jumlah hasil tangkapan secara spasial 
Tabel 6. Presentase ukuran ikan kembung yang tertangkap selama penelitian

\begin{tabular}{lccc}
\hline No & Ukuran Ikan $(\mathbf{c m})$ & Jumlah Ikan & Presentase \\
\hline 1 & $13-14$ & 24 & $6 \%$ \\
2 & $15-16$ & 35 & $10 \%$ \\
3 & $17-18$ & 23 & $7 \%$ \\
4 & $19-20$ & 127 & $37 \%$ \\
5 & $21-22$ & 130 & $38 \%$ \\
6 & $23-24$ & 4 & $1 \%$ \\
\hline
\end{tabular}

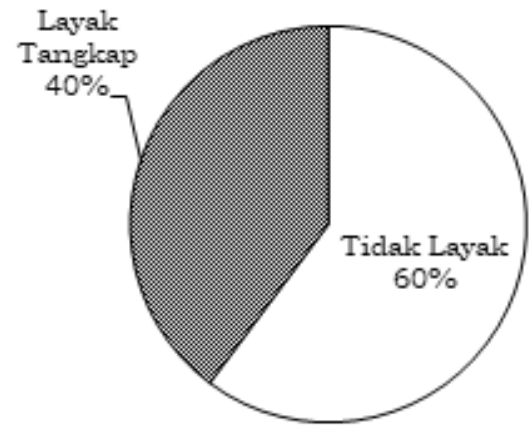

Gambar 5. Presentase ukuran panjang ikan kembung

\section{Variasi kandungan klorofil-a di Selat Sunda}

Sebaran kandungan klorofil-a selama musim peralihan barat mulai dari tahun 2017 hingga 2019 berfluktuatif (Gambar 6). Kandungan klorofil-a pada musim barat pada tahun 2017 tertinggi terjadi pada bulan Oktober dengan nilai $2,06 \mathrm{mg} / \mathrm{m}^{3}$. Kandungan klorofil-a terendah terjadi pada bulan November dengan nilai $0,190 \mathrm{mg} / \mathrm{m}^{3}$. Pada tahun 2018 sebaran klorofil-a dengan nilai terendah terjadi pada bulan November dengan nilai 0,108 mg/ $\mathrm{m}^{3}$. Kandungan klorofil-a tertinggi terjadi pada bulan September dengan nilai 1,316 $\mathrm{mg} / \mathrm{m}^{3}$. Selanjutnya pada tahun 2019, kandungan klorofil-a tertinggi pada bulan September dengan nilai $2,797 \mathrm{mg} / \mathrm{m}^{3}$, sedangkan kandungan klorofil-a terendah terjadi pada bulan November dengan nilai $0,135 \mathrm{mg} / \mathrm{m}^{3}$. Hal ini menunjukkan selama musim peralihan dari tahun 2017-2019 kandungan tertinggi pada bulan September dan Oktober, sedangkan nilai kandungan klorofil-a terendah terjadi pada bulan November. Hal ini sesuai dengan pernyataan Amri et al. 2007 bahwa peningkatan nilai konsentrasi klorofil-a terlihat mulai dari bulan Juni hingga mencapai nilai tertinggi pada bulan September. Musim timur (Juni-Agustus) dan musim peralihan II
(September-November) merupakan musim dengan tingkat kesuburan perairan yang tinggi.

Kandungan klorofil-a selama penelitian menunjukkan berfluktuatif. Secara spasial kandungan klorofil-a tertinggi terdapat di daerah Pulau Peucang, Tj Lesung, dan Teluk Paraja dengan masing-masing konsentrasi klorofil-a 0,861 mg/m ${ }^{3}, 0,807$ $\mathrm{mg} / \mathrm{m}^{3}, 0,896 \mathrm{mg} / \mathrm{m}^{3}$ (Gambar 7). Tingginya konsentrasi klorofil-a diduga karena musim peralihan barat yang mengakibatkan angin kencang pada daerah selatan Selat Sunda. Hal ini sesuai dengan Ramansyah (2009) yang menyatakan kandungan klorofil-a tinggi pada musim timur dan musim peralihan II karena terjadinya angin muson tenggara pada bulan Juli sampai Oktober. Angin muson tenggara memicu terjadinya upwelling di Selatan Jawa karena angin muson tenggara sehingga menyebabkan massa air di Perairan Selatan Jawa mengalami sirkulasi yang sangat kuat.

Klorofil-a merupakan indikator kesuburan suatu perairan. Kandungan klorofil-a yang tinggi akan berpengaruh pada meningkatnya jumlah fitoplankton dan diikuti oleh keberadaan zooplankton. Jumlah fitoplankton dan zooplankton berpengaruh pada organisme perairan lainnya, seperti ikan pelagis kecil (Kasim et al. 2014). 


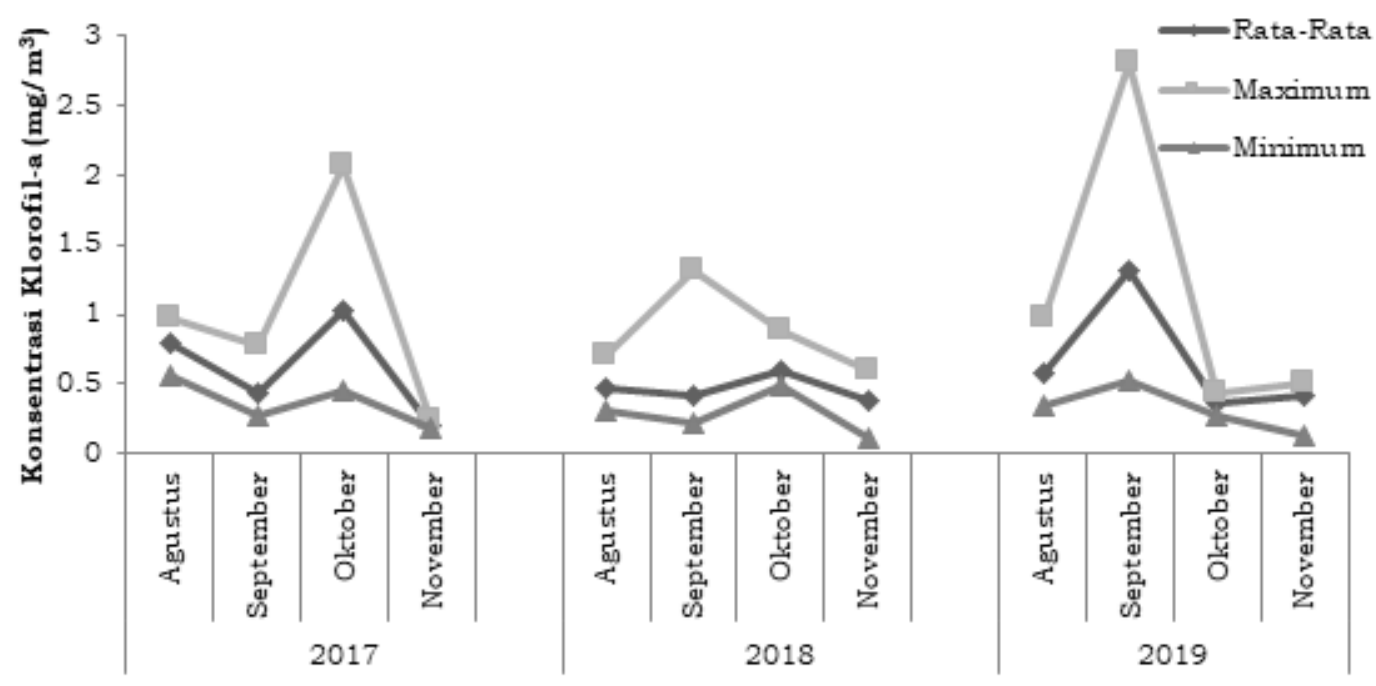

Gambar 6. Konsentrasi klorofil-a tahun 2017-2019

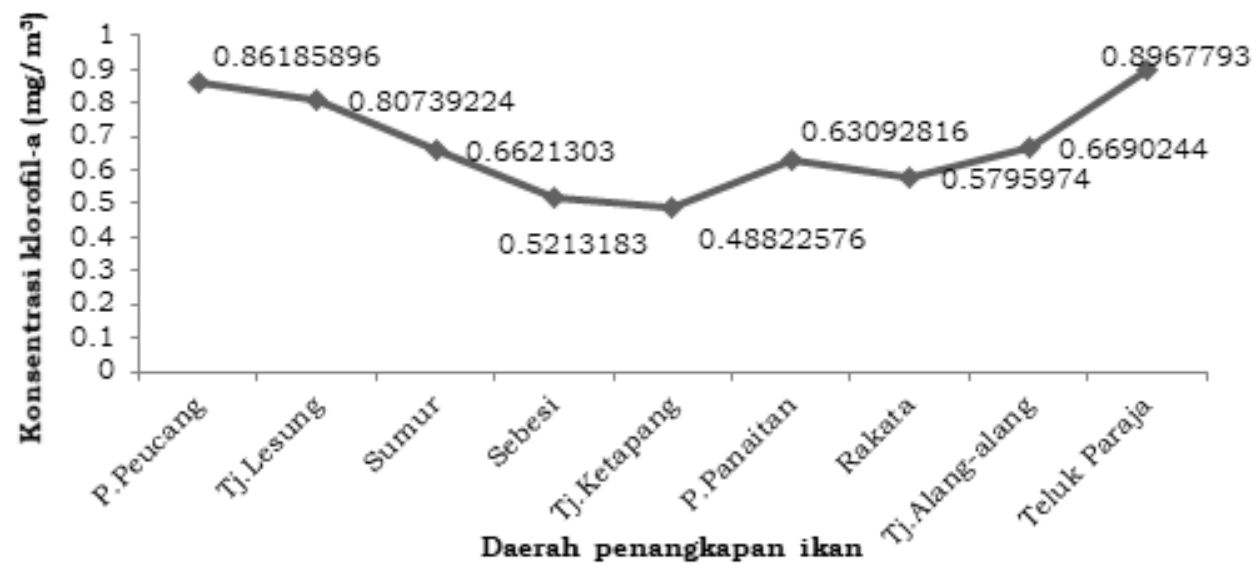

Gambar 7. Konsentrasi klorofil-a secara spasial di Selat Sunda

\section{Hubungan klorofil-a dengan hasil tangkapan ikan kembung di Selat Sunda}

Ikan kembung merupakan salah satu spesies dominan yang tertangkap di Selat Sunda. Ikan kembung termasuk ikan pelagis kecil yang hidupnya bergantung dengan klorofil-a. Hal ini sesuai dengan pernyataan Utami et al. (2014) dan Bhendarkar et al. (2014) yang menyebutkan jenis makanan ikan kembung sebagian besar adalah plankton (klorofil-a). Fitoplankton berperan sebagai produsen primer yaitu organisme yang merubah senyawa anorganik menjadi senyawa organik dengan bantuan sinar matahari (Sihombing et al. 2015). Selain itu klorofil-a merupakan pigmen yang dimiliki oleh fitoplankton yang digunakan dalam proses fotosintesis. Kebiasaan makanan ikan secara alami bergantung pada lingkungan tempat hidup dan faktor-faktor yang mempengaruhi diantaranya adalah habitat, musim, umur dan ukuran ikan, periode mencari makan, kesukaan terhadap jenis tertentu, dan spesies kompetitor (Febyanty dan Syahailatua 2008).

Hubungan antara kandungan klorofil-a dengan hasil tangkapan ikan kembung yang didaratkan di PPP Labuan selama bulan September disajikan pada Gambar 8. Tren peningkatan terjadi pada pertengahan bulan yaitu pada tanggal 1115 September 2020. Secara keseluruhan kondisi peningkatan atau penurunan mengindikasikan bahwa keadaan puncak klorofil-a dan hasil tangkapan ikan kembung tidak terjadi secara bersamaan. Namun klorofil-a berpengaruh terhadap keberadaan ikan kembung di Selat Sunda tetapi dengan jeda waktu (time lag) beberapa hari kemudian. Keadaan yang berbeda menunjukkan adanya variasi konsentrasi klorofil-a memberikan pengaruh langsung atau tidak langsung terhadap produksi ikan (Wudianto 2001).

Hasil uji korelasi silang Spearman sebesar 0,517 menunjukkan bahwa klorofil-a dan hasil tangkapan memiliki hubunganyang 
sedang. Hal ini berarti bahwa keberadaan klorofil-a cukup mempengaruhi jumlah hasil tangkapan ikan kembung. Menurut Wudianto (2001) ikan kembung merupakan ikan pemakan plankton, fitoplankton, maupun zooplankton. Sehingga kelimpahan fitoplankton dan zooplankton menjadi penopang stok makanan sekaligus mampu meningkatkan kelimpahan ikan kembung. Hal ini diduga dipengaruhi oleh adanya waktu sela (time lag) dimana naiknya nilai klorofil-a tidak langsung berdampak, tetapi membutuhkan beberapa waktu sehingga klorofil yang terkandung dalam fitoplankton dimanfaatkan oleh zooplankton sebagai makanannya (Salsabila dan Affandi 2019).

Gambar 9 menunjukkan hubungan konsentrasi klorofil-a dengan CPUE secara spasial. Jika nilai konsentrasi klorofil-a tinggi maka CPUE juga tinggi, seperti pada daerah penangkapan Pulau Peucang, Sumur, dan Pulau Panaitan. Hal ini menunjukkan konsentrasi klorofil-a berpengaruh terhadap CPUE. Daerah penangkapan ikan yang memiliki CPUE tertinggi terdapat di Pulau Peucang, Tanjung Alang-Alang, dan Sebesi, sedangkan daerah penangkapan dengan CPUE terendah terdapat di Sumur dan Tanjung Lesung. CPUE tinggi di daerah tersebut diduga karena tingginya intensitas penangkapan yang dilakukan di daerah tersebut. Meningkatnya kegiatan penangkapan ikan memicu terjadinya persaingan antar nelayan untuk mendapatkan hasil tangkapan (Wiyono 2014).

Konsentrasi klorofil-a tertinggi terdapat di daerah penangkapan Pulau Peucang dan Teluk Paraja. Hal ini diduga karena daerah selatan Selat Sunda berhubungan langsung dengan Samudera Hindia. Amri et al. (2007) menyatakan klorofil-a dibawa oleh arus permukaan menuju Samudera Hindia terutama pada musim timur dan musim peralihan, membawa unsur hara, dan dimanfaatkan penuh oleh fitoplankton untuk berkembang di sebagian besar lokasi di Selat Sunda. Selain itu dikarenakan daerah penangkapan Pulau Peucang terletak dan Teluk Paraja terletak di antara pulau dan dekat dengan pantai sehingga memiliki unsur kandungan klorofil yang cukup tinggi. Pendapat lain juga menyebutkan kandungan klorofil-a di Selat Sunda dipengaruhi oleh massa air dari Laut Jawa. Arus pada musim timur dan musim peralihan relatif kuat dari arah timur (Laut Jawa) menuju Samudera Hindia. Air laut dari Jawa lebih dominan mendorong massa air hangat dengan kandungan klorofil tinggi masuk ke Selat Sunda (Aeni 2012), sehingga menyebabkan daerah penangkapan tersebut memiliki kandungan klorofil-a yang tinggi.

\section{Daerah penangkapan ikan kembung di perairan Selat Sunda}

Daerah penangkapan ikan kembung di Selat Sunda bulan September 2020 dievaluasi berdasarkan 3 indikator yaitu CPUE, ukuran panjang ikan yang tertangkap, dan kandungan klorofil-a. Nilai CPUE ratarata harian pada penelitian ini yaitu 3,72. Daerah penangkapan ikan yang termasuk kategori CPUE tinggi adalah Pulau Peucang, Sebesi, dan Tanjung Alang-Alang (Gambar 10). Kategori daerah penangkapan ikan yang memiliki konsentrasi klorofil-a tinggi adalah Pulau Peucang, Pulau Panaitan Tanjung Lesung, Sumur, Sebesi, Tanjung Ketapang, Rakata, Tanjung Alang-Alang, dan Teluk Paraja (Gambar 11).

Kategori ukuran ikan layak tangkap dan tidak layak tangkap penting untuk diperhatikan demi keberlanjutan sumberdaya. Jika ikan kembung yang belum layak tangkap ditangkap secara terus menerus, maka tingkat perkembangbiakan kembung semakin menurun dan bukan tidak mungkin kedepannya akan mengalami penurunan ukuran ikan. Hal ini dikarenakan tekanan penangkapan yang tidak layak tangkap (Kasmi et al. 2017; Wujdi 2013). Selain itu diperlukan penentuan waktu/musim ikan kembung tersebut akan memijah. Menurut Nugroho dan Murdijah (2006), ikan kembung akan memijah pertama kali pada umur dua tahun yang dilakukan secara periodik dengan selang waktu pemijahan dua kali bulan Maret dan Oktober. Oleh karena itu dibutuhkan pengelolaan perikanan untuk mencapai keberlanjutan sumberdaya (Tarigan et al. 2019). Selain itu diperlukan adanya informasi yang komprehensif terkait ukuran ikan yang layak tangkap dan musim pemijahan demi menjaga keberlanjutan sumberdaya ikan kembung.

Daerah penangkapan ikan kembung di Perairan Selat Sunda didominasi kategori tidak potensial. Hal ini dikarenakan ukuran ikan yang tertangkap didominasi oleh kategori tidak layak tangkap (Tabel 7). Daerah yang termasuk kategori layak tangkap adalah Pulau Peucang, Pulau Panaitan, Tanjung Alang-Alang, dan Teluk Paraja, sedangkan kategori tidak layak tangkap yaitu Tanjung Lesung, Sumur, 
Sebesi, Tanjung Ketapang, dan Rakata (Gambar 12).

Secara keseluruhan hasil penelitian menunjukkan bahwa kategori tidak layak tangkap sebesar 60\%. Hal ini menunjukkan bahwa kategori layak tangkap lebih dominan dibandingkan dengan kategori layak tangkap (Gambar 5). Oleh karena itu diperlukan beberapa pengendalian yaitu dengan mengatur jumlah armada penangkapan, melakukan pengaturan zona penangkapan dan musim penangkapan ikan kembung, dan mengatur ukuran ikan kembung yang boleh ditangkap. Selain itu, mengatur jarak dan daerah penangkapan untuk melindungi stok ikan, membatasi upaya penangkapan (Bunyamin et al. 2016). Selanjutnya menurut Tarigan et al. (2018) dan Simbolon et al. (2020) yang menyatakan perlu adanya pengawasan terhadap daerah penangkapan ikan. Pengendalian dan aturan tersebut diperlukan untuk menjaga keberlanjutan sumberdaya ikan kembung di Selat Sunda.
Pada umumnya daerah penangkapan ikan tidak ada yang bersifat tetap, selalu berubah dan berpindah mengikuti pergerakan kondisi lingkungan, yang secara alamiah ikan akan memilih habitat yang lebih sesuai. Habitat tersebut sangat dipengaruhi oleh kondisi atau parameter oseanografi perairan seperti suhu permukaan laut, salinitas, klorofil-a, kecepatan arus, dan sebagainya (Indrayani et al. 2012). Berdasarkan wawancara dan observasi kegiatan operasi penangkapan ikan banyak dilakukan di bagian selatan Perairan Selat Sunda (Gambar 13). Hal ini dikarenakan keterbatasan armada penangkapan dan pengalaman nelayan yang menyatakan faktor cuaca pada musim peralihan II yang membuat nelayan kurang mampu untuk menjangkau daerah penangkapan yang lebih jauh. Selain itu relatif lebih aman menuju daerah penangkapan ikan karena diapit oleh beberapa pulau, mengingat angin pada musim peralihan yang cukup kencang.

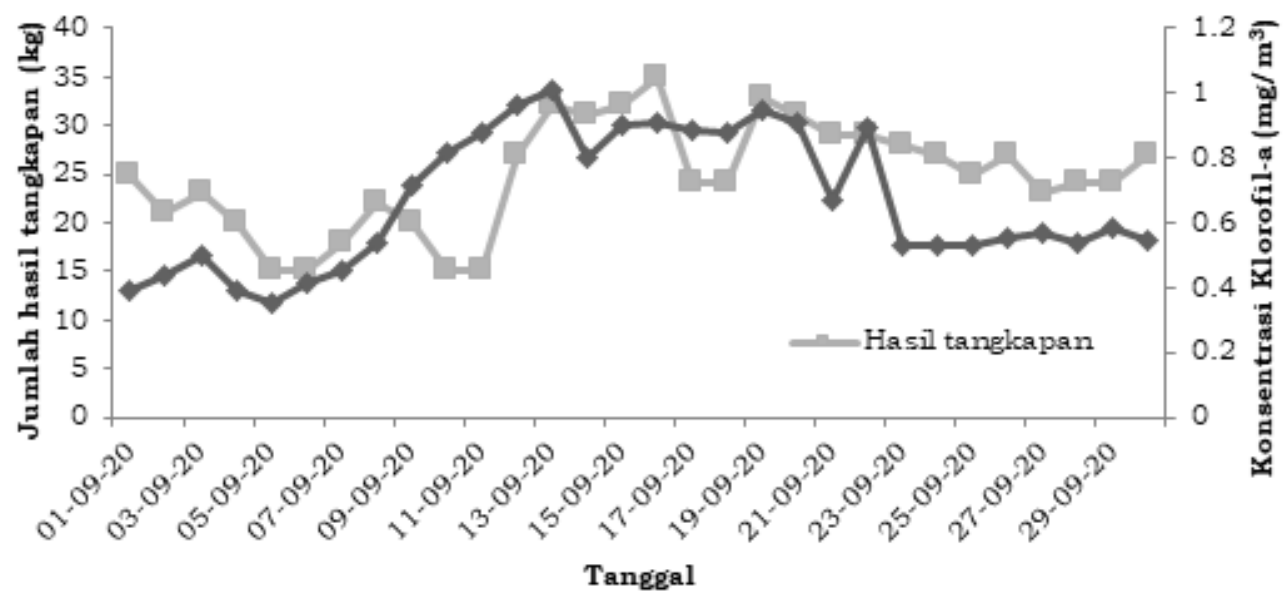

Gambar 8. Hubungan klorofil-a dengan hasil tangkapan ikan kembung

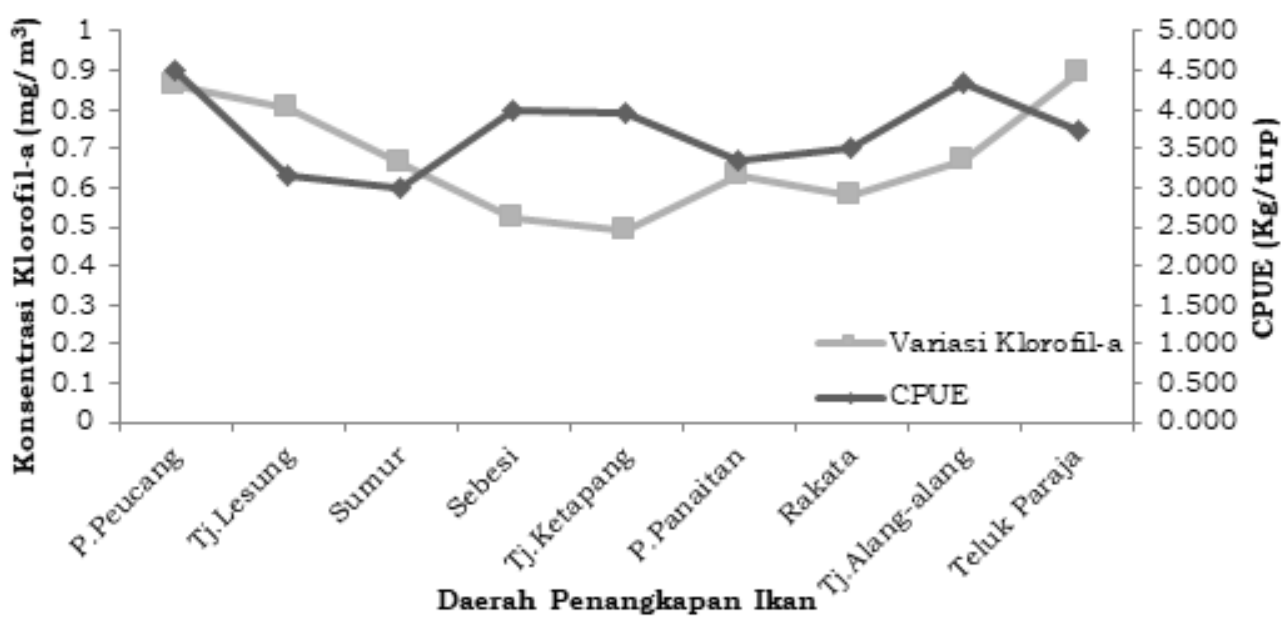

Gambar 9. Hubungan konsentrasi klorofil-a dengan CPUE secara spasial 


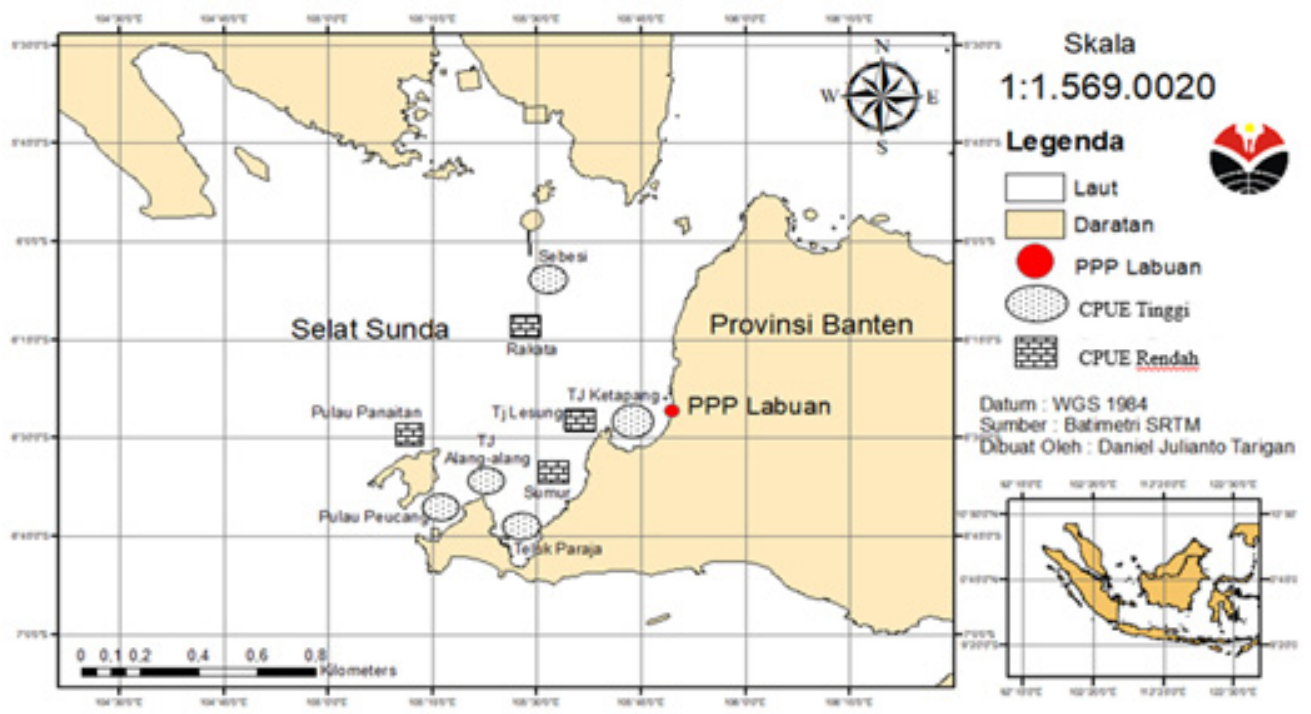

Gambar 10. Daerah penangkapan ikan berdasarkan CPUE

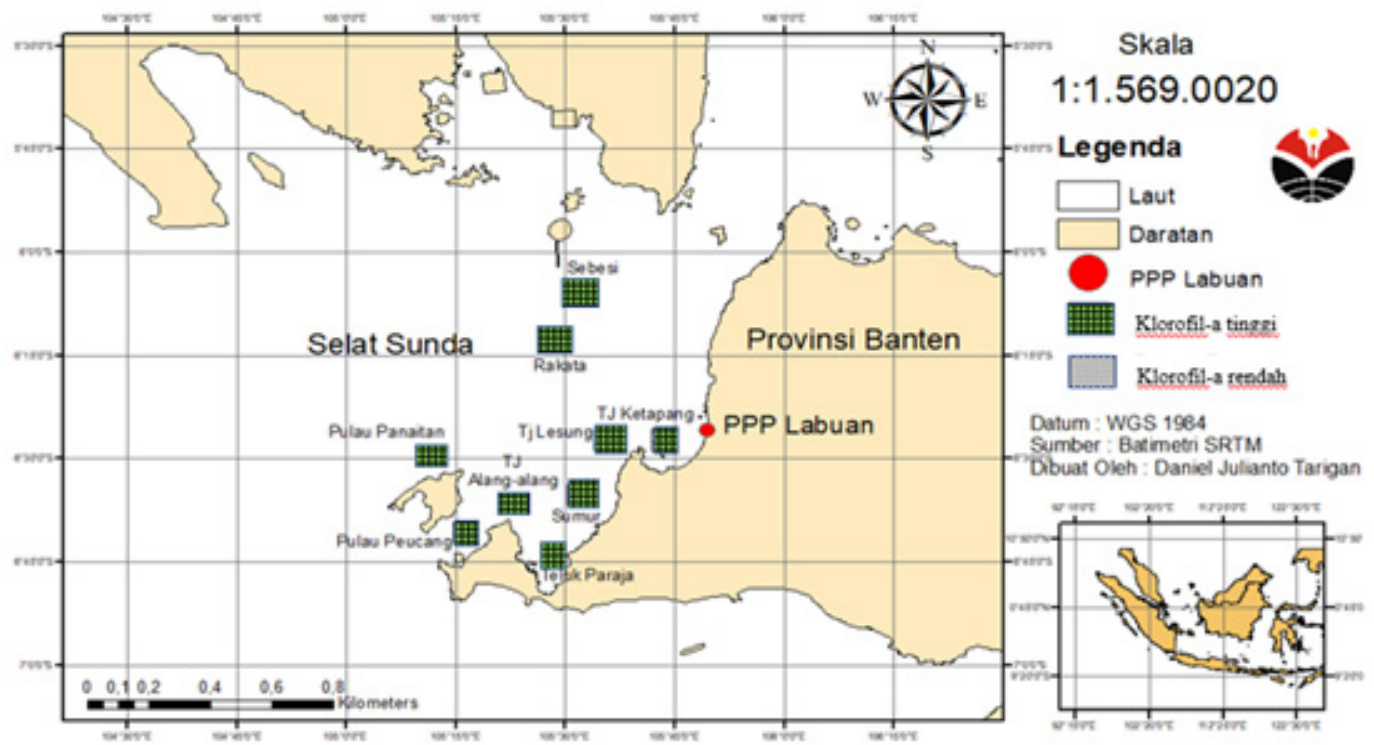

Gambar 11. Daerah penangkapan ikan berdasarkan kandungan klorofil-a

Tabel 7. Evaluasi daerah penangkapan ikan berdasarkan kategori CPUE, ukuran panjang ikan dan klorofil-a

\begin{tabular}{|c|c|c|c|c|c|c|c|c|}
\hline \multirow{3}{*}{$\begin{array}{c}\text { Daerah } \\
\text { Penangkapan } \\
\text { Ikan }\end{array}$} & \multicolumn{6}{|c|}{ Indikator DPI } & \multirow{2}{*}{\multicolumn{2}{|c|}{ Kategori DPI }} \\
\hline & \multicolumn{2}{|c|}{ CPUE } & \multicolumn{2}{|c|}{$\begin{array}{c}\text { Ukuran Panjang } \\
\text { Ikan }\end{array}$} & \multicolumn{2}{|c|}{$\begin{array}{l}\text { Klorofil-a } \\
\left(\mathrm{mg} / \mathrm{m}^{3}\right)\end{array}$} & & \\
\hline & D & B & $E(\mathrm{~cm})$ & B & $\mathbf{F}$ & B & Total & Kategori \\
\hline P.Peucang & 4,50 & 1 & 21,6 & 3 & 0.861 & 1 & 5 & $\mathrm{P}$ \\
\hline Tj.Lesung & 3,15 & 0 & 20,5 & 0 & 0.807 & 1 & 1 & $\mathrm{TP}$ \\
\hline Sumur & 3,00 & 0 & 19,5 & 0 & 0.662 & 1 & 1 & TP \\
\hline Sebesi & 4,00 & 1 & 17,8 & 0 & 0.521 & 1 & 2 & $\mathrm{TP}$ \\
\hline Tj.Ketapang & 3,95 & 1 & 19 & 0 & 0.488 & 1 & 2 & $\mathrm{TP}$ \\
\hline P.Panaitan & 3,35 & 0 & 21 & 3 & 0.630 & 1 & 4 & $\mathrm{P}$ \\
\hline Rakata & 3,50 & 0 & 16,7 & 0 & 0.579 & 1 & 1 & $\mathrm{TP}$ \\
\hline Tj.Alang-alang & 4,35 & 1 & 21,4 & 3 & 0.669 & 1 & 5 & $\mathrm{P}$ \\
\hline Teluk Paraja & 3,75 & 1 & 21,8 & 3 & 0.896 & 1 & 5 & $\mathrm{P}$ \\
\hline
\end{tabular}




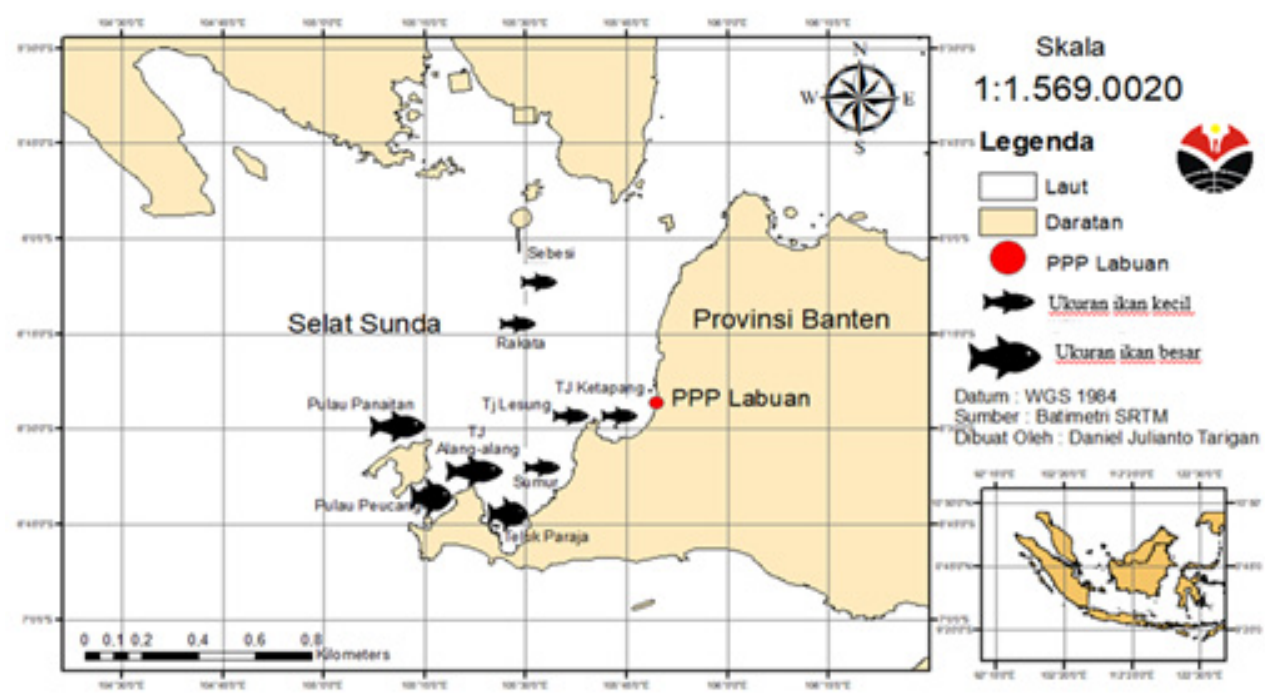

Gambar 12. Daerah penangkapan ikan berdasarkan ukuran panjang ikan kembung

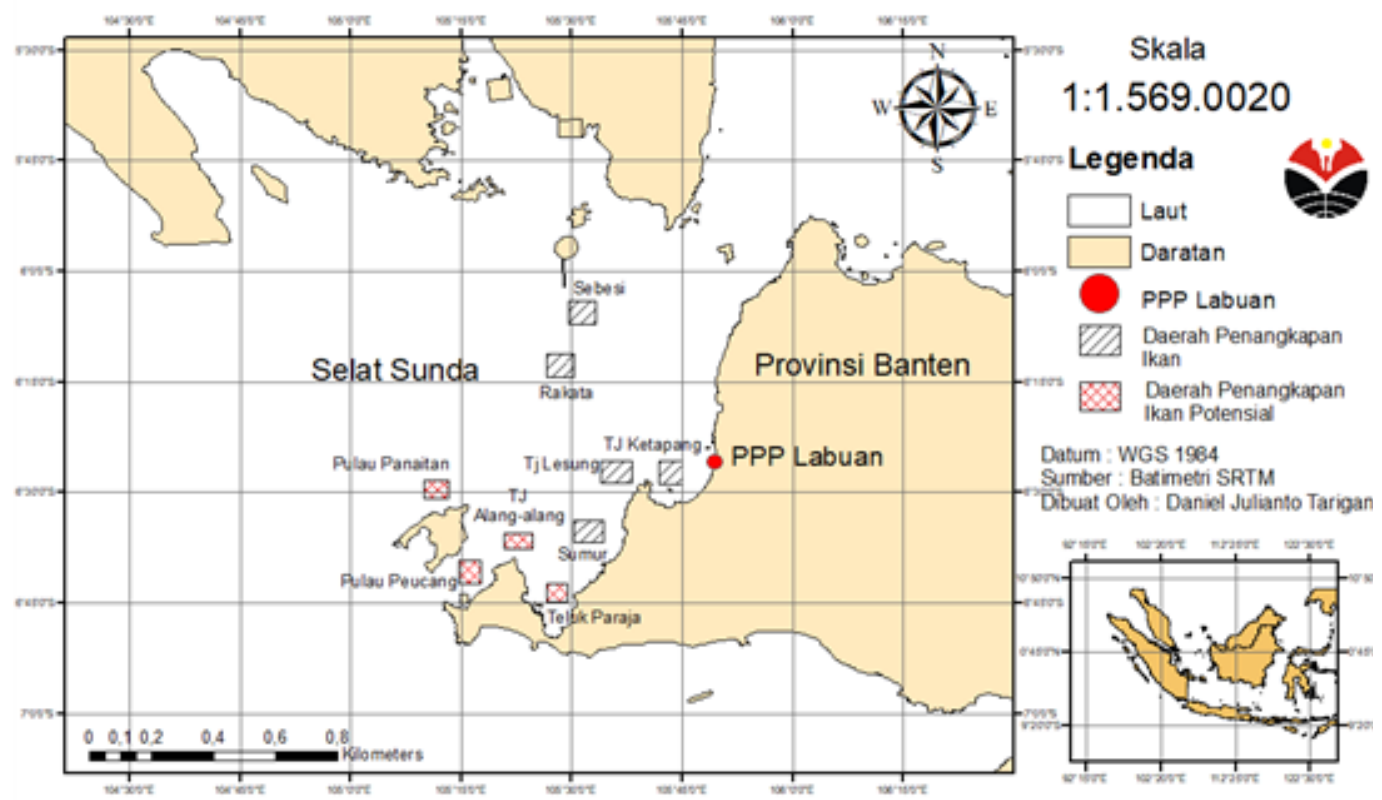

Gambar 13. Peta daerah penangkapan ikan kembung di Selat Sunda

\section{KESIMPULAN DAN SARAN}

\section{Kesimpulan}

Jumlah total hasil tangkapan ikan kembung di Perairan Selat Sunda selama penelitian yaitu $741 \mathrm{~kg}$. Ukuran panjang ikan kembung yang tertangkap didominasi kategori ikan tidak layak tangkap dengan persentase $60 \%$. Rata-rata sebaran spasial kandungan klorofil-a yaitu 0,6796 mg/ $\mathrm{m}^{3}$. Kategori ukuran ikan layak tangkap terdapat di daerah penangkapan Pulau Peucang, Pulau Panaitan, Teluk Paraja, dan Tanjung Alang-Alang. Kandungan klorofil-a secara keseluruhan termasuk kategori tinggi. Daerah penangkapan yang termasuk kategori potensial yaitu Pulau
Peucang, Pulau Panaitan, Tanjung Alangalang, dan Teluk Paraja sedangkan daerah penangkapan yang tidak potensial yaitu Tanjung Lesung, Sumur, Sebesi, Tanjung Ketapang, dan Rakata.

\section{Saran}

Penelitian lanjutan terkait parameter oseanografi lain seperti suhu, salinitas, dan arus diperlukan untuk mendapatkan data yang lebih komprehensif.

\section{UCAPAN TERIMA KASIH}

Terima kasih kepada LPPM UPI atas dukungan dana sehingga penelitian ini 
dapat terlaksana, dan kepada semua pihak yang mendukung kegiatan penelitian ini.

\section{DAFTAR PUSTAKA}

Abubakar S, Riyadi S, Tahir I. 2019. Pendugaan Ukuran Pertama Kali Matang Gonad Ikan Kembung (Rastrelliger sp) di Perairan Desa Sidangoli Dehe Kecamatan Jailolo Selatan Kabupaten Halmahera Barat. Jurnal Biologi Tropis. 19(1): 42-51.

Aeni N. 2012. Analisis Suhu Permukaan Laut dan Klorofil-a dari Citra Aqua Modis serta Hubungannya dengan Hasil Tangkapan Ikan Pelagis di Selat Sunda [Skripsi]. Bogor: Insitut Pertanian Bogor.

Amri K, Manurung D, Siregar VP. 2007. Dinamika Kondisi Oseanografi Musiman Perairan Selat Sunda dari Analisis Data Multitemporal. Jurnal Penelitian Perikanan Indonesia. 13(3): 191-199.

Bhendarkar MP, Naik SD, Sonone AD, Wankhade HP, Joshi HD. 2014. Feeding Biology of the of Indian mackerel, Rastrelliger kanagurta (Cuvier, 1817) off Ratnagiri Coast, Maharashtra, India. 20(3): 11471152.

Boer M, Aziz KA. 2007. Gejala Tangkap Lebih Perikanan Pelagis Kecil di Perairan Selat Sunda. Jurnal Ilmu-Ilmu Perairan dan Perikanan Indonesia. 14(2): 167-172.

Bunyamin, Wahono HPM, Subhakti HOD. 2016. Analisis Pengelolaan Penangkapan Ikan Kembung Lelaki (Rastrelliger kanagurta) secara Berkelanjutan di Perairan Selat Lombok. Jurnal Penyuluhan Perikanan dan Kelautan. 10(3): 181191.

Febyanty F, Syahailatua A. 2008. Kebiasaan Makanan Ikan Terbang, Hirundicthys oxycephalus dan Cheilopogon cyanopterus, di Perairan Selat Makasar [Laporan Penelitian]. Fakultas Perikanan dan Ilmu Kelautan \& Pusat Penelitian Oseanografi, Lembaga Ilmu Pengetahuan Indonesia. 1-8.

Indrayani, Mallawa A, Zainuddin M. 2012. Penentuan Karakteristik Habitat Daerah Potensial Ikan Pelagis Kecil dengan Pendekatan Spasial di Perairan Sinjai [Jurnal Penelitian]. Fakultas Ilmu Kelautan, Universitas Hasanuddin, Makassar, $10 \mathrm{hlm}$.

Ispahdianto D, Fitri ADP, Arisyanto. 2016. Analisis Hasil Tangkapan Ikan Kembung (Rastrelliger $s p$ ) dan Cumi-Cumi (Lolligo $s p$ ) pada Alat Tangkap Mini Purse Seine di Perairan Morodemak, Kabupaten Demak Jawa Tengah. Journal of Fisheries Resources Utilization Management and Technology. 5(1): 153-161.

Kasim K, Triwahyuni S, Wujdi A. 2014. Hubungan Ikan Pelagis dengan Konsentrasi Klorofil-a di Laut Jawa. Bawal. 6(1): 21-29.

Kasmi MS, Hadi W, Kantun. 2017. Biologi Reproduksi Ikan Kembung Lelaki, Rastreliger kanagurta (Cuvier, 1816) di Perairan Pesisir Takalar, Sulawesi Selatan. Jurnal Iktiologi Indonesia. 17(3): 259-271.

Lubis ZA, Yonvitner, Fahrudin A. 2019. Indikator Stok Ikan Kembung (Rastrelliger kanagurta Cuvier, 1816) dan Suhu Perairan Selat Sunda. Jurnal Pengelolaan Perikanan Tropis. $3(1): 38-43$.

Meliani F. 2006. Kajian Konsentrasi dan Sebaran Spasial Klorofil-a di Perairan Teluk Jakarta Menggunakan Citra Satelit Aqua MODIS [Skripsi]. Bogor: Fakultas Perikanan dan Ilmu Kelautan, Institut Pertanian Bogor.

Musbir, Mallawa A, Sudirman, Najamudin. 2006. Pendugaan Ukuran Pertama Kali Matang Gonad Ikan Kembung, Rastrelliger kanagurta di Perairan Laut Flores Sulawesi Selatan. Program Pasca Sarjana Jurusan Sains dan Teknologi, Fakultas Ilmu Kelautan dan Perikanan, Universitas Hasanuddin. Makassar. 6(1): 19-26.

Nugroho A, Murdijah. 2006. Hubungan Panjang Berat, Perbandingan Jenis Kelamin, dan Tingkat Kematangan Gonad Ikan Kembung di Laut Banda. Jurnal Penelitian Perikanan Indonesia. 12: 195-200.

Prahadina VD, Boer M, Fahrudin A. 2015. Sumberdaya Ikan Kembung (Rastrelliger kanagurta Cuvier 1817) di Perairan Selat Sunda yang Didaratkan di PPP Labuan, Banten. Marine Fisheries. 6(2): 169-175.

Priatna A, Natsir M. 2008. Pola Sebaran Ikan pada Musim Barat dan Peralihan 
di Perairan Utawa Jawa Tengah. Penelitian Perikanan Indonesia. 14(1): 63-72.

Purwaningtyas SE, Sugianti Y, Hartati ST. 2006. Hasil Tangkapan Ikan dengan Menggunakan Bubu di Teluk Saleh. Nusa Tenggara Barat. Prosiding Seminar Nasional Ikan IV. 255-264.

Ramansyah F. 2009. Penentuan Pola Sebaran Konsentrasi Klorofil-a di Selat Sunda dan Perairan Sekitarnya dengan Menggunakan Data Inderaan Aqua Modis [Skripsi]. Bogor: Institut Pertanian Bogor.

Salsabila S, Affandi R. 2019. Preferensi Makanan Ikan Kembung Lelaki (Rastrelliger kanagurta Cuvier, 1816) terhadap Klorofil-A. Jurnal Pengelolaan Perikanan Tropis. 3(1): 44-50.

Sarasati W, Boer M, Sulistiono. 2016. Status Stok Rastrelliger spp. sebagai Dasar Pengelolaan Perikanan. Jurnal Perikanan Universitas Gadjah Mada. (18)2: 73-81.

Sihombing IN, Hutabarat A, Sulardiono B. 2015. Kajian Kesuburan Perairan berdasarkan Unsur Hara (N,P) dan Fitoplankton di Sungai Tulung Demak. Diponegoro Journal of Maquares. 4(4): 119-127.

Simbolon D. 2008. Pendugaan Daerah Penangkapan Ikan Tongkol Berdasarkan Pendekatan Suhu Permukaan Laut Deteksi Satelit dan Hasil Tangkapan di Perairan Teluk Palabuhanratu. Jurnal Litbangda NTT. 4: 23-30.

Simbolon D, Girsang HS. 2009. Hubungan Antara Kandungan Klorofil-a dengan Hasil Tangkapan Tongkol di Daerah Penangkapan Ikan Perairan Pelabuhanratu. Jurnal Penelitian Perikanan Indonesia. 15(4): 297-305.

Simbolon D. 2017. Daerah Penangkapan Ikan dalam Pengembangan Perikanan Tangkap Berkelanjutan Simbolon. Bogor (ID): Orasi Ilmiah Guru Besar IPB. 52hlm.

Simbolon D. 2020. Daerah Penangkapan Ikan: Perencanaan, Degradasi, dan Pengelolaan. Bogor (ID): IPB Press.

Simbolon D, Tarigan DJ, Yolanda DF, Antika MR. 2020. Determination of potential fishing zones of aerolate grouper (Epinephelus areolatus) based on analysis of productivity, gonad maturity and fish length in Karimunjawa National Park, Indonesia. AACL Bioflux. 13(2):833848.

Siregar S. 2004. Statistik Terapan untuk Penelitian. Jakarta (ID): PT Gramedia Widiasarana Indonesia.

Siregar MS. 2015. Status Stok Sumberdaya Ikan Kembung Lelaki (Rastrelliger kanagurta Cuvier, 1817) di Perairan Selat Sunda [Skripsi]. Bogor: Institut Pertanian Bogor.

Sugiyono. 2007. Metode Penelitian Pendidikan Kuantitatif, Kualitatif dan R \& D. Bandung [ID]: Alfabeta.

Sugiyono. 2011. Statistika untuk Penelitian. Bandung (ID): Alfabeta.

Surbakti CN. 2012. Analisis Musim dan Daerah Penangkapan Ikan Teri Berdasarkan Kandungan Klorofil-a di Perairan Sibolga, Sumatera Utara [Skripsi]. Bogor: Departemen Pemanfaatan Sumberdaya Perikanan, Instutut Pertanian Bogor.

Tarigan DJ. 2016. Pendugaan Daerah Penangkapan Ikan Lemuru Berdasarkan Kandungan Klorofil-a dan Komposisi Hasil Tangkapan yang Didaratkan di PPN Pengambengan [Skripsi]. Bogor: Fakultas Perikanan dan Ilmu Kelautan, Institut Pertanian Bogor.

Tarigan DJ, Simbolon D, Wiryawan B. 2018. Strategi Pengelolaan Perikanan Gurita di Kabupaten Banggai Laut, Provinsi Sulawesi Tengah. Jurnal Teknologi Perikanan dan Kelautan. 9(1): 13-24.

Tarigan DJ, Simbolon D, Wiryawan B. 2019. Evaluasi Keberlanjutan Perikanan Gurita dengan Indikator EAFM (Ecosystem Approach to Fisheries Management) di Kabupaten Banggai Laut. Jurnal Marine Fisheries. 10(1): 83-94.

Tubalawony, S. 2008. Dinamika Massa Air Lapisan Ekman Perairan Selatan Jawa-Sumbawa Selama Muson Tenggara. Torani. 17(2): 140-150.

Utami MNF, Redjeki S, Supriyantini E. 2014. Komposisi Isi Lambung Ikan Kembung Lelaki (Rastrelliger kanagurta) di Rembang. Journal of Marine Research. 2(3): 99-106.

Wiyono ES. 2014. Optimizing Purse Seine Fishing Operations in the Java Sea, Indonesia. Aquaculture, Aquarium, Conservation \& Legislation. 7(6): 475482. 
Wudianto. 2001. Karakteristik Gerombolan Ikan Lemuru (Sardinella lemuru Bleeker, 1853) di Perairan Selat Bali. Jurnal Penelitian Perikanan Indonesia Edisi Sumberdaya dan Penangkapan. 7 (3): 70-77.

Wujdi A. 2013. Beberapa Parameter Populasi Ikan Lemuru (Sardinella lemuru) di Perairan Selat Bali. Jurnal Widya Riset Perikanan Tangkap. 16(2): 211218.

Zen M, Simbolon D, Gaol JL, Hartojo W. 2005. Pengkajian Zona Potensial Penangkapan Ikan Kembung (Rastrelliger spp) di Kabupaten Asahan Sumatera Utara. Bogor (ID). Seminar Nasional Perikanan Tangkap. 303-314. 